\title{
Inhaled Corticosteroids as an Associated Risk Factor for Asthmatic Pneumonia: A Literature Review
}

\author{
Zin Mar Htun ${ }^{1}$, Israa Aldawudi ${ }^{2}$, Prakash C. Katwal ${ }^{1}$, Srood Jirjees ${ }^{3}$, Safeera Khan ${ }^{1}$ \\ 1. Internal Medicine, California Institute of Behavioral Neurosciences \& Psychology, Fairfield, USA 2. Radiology, \\ California Institute of Behavioral Neurosciences \& Psychology, Fairfield, USA 3. Neurology, California Institute of \\ Behavioral Neurosciences \& Psychology, Fairfield, USA
}

Corresponding author: Zin Mar Htun, zinmarhtun28@gmail.com

\begin{abstract}
Asthma patients have commonly been prescribed inhaled corticosteroids (ICSs) as the first line of control therapy. ICSs are associated with an increased risk of pneumonia in chronic obstructive airway disease (COPD) patients. However, the evidence remains controversial in asthma patients. Several observational studies reported an increased risk of pneumonia; however, COPD patients were not excluded clearly in these studies. In observational studies that excluded COPD patients and in randomized controlled trials, ICS use was not found to be associated with the risk of pneumonia. Hence, COPD patients should be excluded in future studies, and the currently available evidence demonstrates that ICS use is not associated with an increased risk of pneumonia in asthma patients.
\end{abstract}

Categories: Internal Medicine, Infectious Disease, Pulmonology

Keywords: asthma, inhaled corticosteroids, pneumonia, literature review, budesonide, fluticasone, infection, chronic obstructive pulmonary disease

\section{Introduction And Background}

Asthma is a chronic airway disease that has significant morbidity, mortality, and healthcare burden. Glucocorticoids are the cornerstone of maintenance therapy for persistent asthma to prevent exacerbations and optional control and are recommended therapy in major guidelines [1]. Inhaled corticosteroid (ICS) improves asthma control. Subsequently, it improves the quality of life as proven in GOAL study (The Gaining Optimal Asthma Control Study), a randomized controlled trial (RCT) conducted in 2002 [2]. Both systemic and inhaled steroids are widely used in both acute exacerbations and chronic persistent asthma. They also are associated with significant side effects. Systemic steroids are associated with osteoporosis, hyperglycemia, fluid retention, and immunosuppression. ICS is associated with local effects such as oropharyngeal candidiasis and dysphonia, even though they have less systemic side effects.

Received 04/18/2020

Review began 06/05/2020 Review ended 06/10/2020 Published 06/20/2020

\section{(c) Copyright 2020}

Htun et al. This is an open access article distributed under the terms of the Creative Commons Attribution License CC-BY 4.0., which permits unrestricted use, distribution, and reproduction in any medium, provided the original author and source are credited.
Pneumonia is a condition commonly associated with chronic lung diseases such as asthma, chronic obstructive airway disease (COPD), and interstitial lung diseases. It has significant morbidity, mortality, and a global healthcare burden. In 2017, influenza and pneumonia had an age-adjusted death rate of 14.3 according to the Centers for Disease Control and Prevention (CDC) [3]. Nearly one-half (48\%) of patients hospitalized with community-acquired pneumonia developed severe sepsis, and $4.5 \%$ of them developed septic shock [4]. Hence, it is important to recognize risk factors of pneumonia and patient population that are susceptible to pneumonia.

Whether ICS increases the risk of lung infections has been a matter of debate in recent years. Clinical equipoise is observed in determining the association of ICS with pneumonia, tuberculous, and nontuberculous mycobacterial infections in both asthma and COPD patients. The evidence supporting the risk of pneumonia in COPD patients appears to be stronger [5-7]. However, fewer studies are focusing on asthma patients, and data remains controversial. In asthma patients, asthma itself is an independent risk factor for invasive pneumococcal disease $[8,9]$. Additionally, ICS has also been associated with mycobacterial infections in both asthma and COPD patients $[10,11]$. In this review, we would like to focus on the risk of pneumonia associated with ICS use in asthma patients.

\section{Review}

\section{Methods}

The literature search was conducted on PubMed and Google Scholar by using keywords "asthma," "inhaled corticosteroids," and "pneumonia". The search was then narrowed down by using the Boolean operator "AND", as given in Table 1. 


\section{Cureus}

\begin{tabular}{|c|c|c|c|}
\hline Database & Date searched & Search term & Total studies \\
\hline PubMed & January 27, 2020 & Asthma & 136,609 \\
\hline PubMed & January 27, 2020 & Inhaled corticosteroids & 18,740 \\
\hline PubMed & January 27, 2020 & Asthma AND inhaled corticosteroids & 11,760 \\
\hline PubMed & January 27, 2020 & Asthma AND inhaled corticosteroids AND pneumonia & 238 \\
\hline Google Scholar & January 28, 2020 & Asthma AND inhaled corticosteroids AND pneumonia & 34,100 \\
\hline
\end{tabular}

TABLE 1: Literature search results

Articles published in languages other than English and of irrelevant content such as studies including only COPD population or those on risk of infections other than pneumonia were excluded. A total of six observational studies, three RCTs, and one meta-analysis, including 86 RCTs, will be discussed in this review.

\section{Discussion}

The available evidence in literature can be divided into observational studies and RCTs. Depending on the study protocol, COPD patients were excluded in some studies but not in others. Interestingly, the risk of pneumonia varies depending on whether COPD patients were excluded and also varies among observational studies and RCTs.

\section{Observational Studies}

Observational studies conducted on the risk of pneumonia in asthma and COPD patients are given in Table 2 .

\begin{tabular}{|c|c|c|c|c|c|c|}
\hline Source & $\begin{array}{l}\text { Age } \\
\text { group }\end{array}$ & $\begin{array}{l}\text { No. of } \\
\text { patients }\end{array}$ & COPD excluded & Study type & Result & $95 \% \mathrm{Cl}$ \\
\hline Kim et al. [12] & $\begin{array}{l}>15 \\
\text { years }\end{array}$ & 831,613 & No; LAMA users included & Asthma ICS/asthma non-ICS & OR: 1.38 & $\begin{array}{l}1.36- \\
1.41\end{array}$ \\
\hline $\begin{array}{l}\text { Ekbom et al. } \\
\text { [13] }\end{array}$ & $\begin{array}{l}20-44 \\
\text { years }\end{array}$ & 7,284 & No; asthma self-reported diagnosis & $\begin{array}{l}\text { Hospitalization/no- } \\
\text { hospitalization }\end{array}$ & HR: 3.35 & $\begin{array}{l}1.97- \\
5.02\end{array}$ \\
\hline $\begin{array}{l}\text { McKeever et al. } \\
\text { [14] }\end{array}$ & $\begin{array}{l}18-80 \\
\text { years }\end{array}$ & 43,169 & Yes & Pneumonıa/no pneumonıa & OR: 1.24 & $\begin{array}{l}1.5- \\
1.79\end{array}$ \\
\hline Festic et al. [15] & $43-10$ & 1,234 & Yes; asthma and CUPD reported & Asthma ICS/asthma non-ICS & $\begin{array}{l}\text { OR: } 1.07 \text { for } \\
\text { asthma }\end{array}$ & $\begin{array}{l}0.61- \\
1.87\end{array}$ \\
\hline & S & & 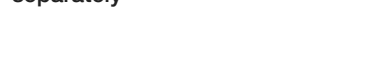 & & $\begin{array}{l}\text { OR: } 1.4 \text { for } \\
\text { COPD }\end{array}$ & $\begin{array}{l}0.95- \\
2.09\end{array}$ \\
\hline To et al. [16] & $\begin{array}{l}16-83 \\
\text { years }\end{array}$ & 62 & Yes & Asthma ICS/asthma non-ICS & No difference & \\
\hline Almirall et al. & $>14$ & 2662 & Yes; astnma and CUPD reported & Pneumonia/pneumonia (case- & $\begin{array}{l}\text { OR: } 1.1 \text { for } \\
\text { asthma }\end{array}$ & $\begin{array}{l}0.4- \\
3.00\end{array}$ \\
\hline$[1 I]$ & yedars & & separdaty & Comitroi) & $\begin{array}{l}\text { OR: } 3.26 \text { for } \\
\text { COPD }\end{array}$ & $\begin{array}{l}1.07- \\
9.98\end{array}$ \\
\hline
\end{tabular}

\section{TABLE 2: Observational studies conducted on the risk of pneumonia in asthma and COPD} patients and their results

COPD, chronic obstructive pulmonary disease; LAMA, long-acting muscarinic agonists; ICS, inhaled corticosteroids; OR, odds ratio; CI, confidence interval; HR, hazard ratio 
The largest retrospective observational study was conducted by Kim et al. using the Health Insurance Review and Assessment Service (HIRA) database in Korea [12]. The authors adjusted for limited confounders of age, hospital type, Charlson comorbidity index, and medical use. COPD by itself was not adjusted. They noticed an increased risk of pneumonia with the use of inhaled steroids (OR: 1.38; 95\% CI: [1.46-1.41]. In the study by Ekbom et al., the asthma diagnosis was obtained through a questionnaire and a national registry of these patients for pneumonia admissions [13]. COPD patients were not excluded. They noticed an increased risk of pneumonia in asthma patients (hazard ratio [HR]: 3.35 [1.97-5.02]) more with the use of fluticasone inhaler (incidence risk ratio [IRR]: 7.92 [2.32-27.0]), and no significant association was observed with budesonide use.

In studies in which COPD patients were excluded, the risk of pneumonia was found to be not as high as in studies in which COPD patients were not excluded. McKeever et al. performed a nested case-control study using the Health Improvement Network database [14]. COPD patients were excluded in McKeever's study. The study reported that patients with asthma and pneumonia or upper respiratory tract infections were more likely to be using steroids (OR: 1.24; 95\% CI: 1.15-1.33) after adjusting for confounders. Festic et al. investigated the risk of pneumonia requiring admission with the prehospital use and after adjusting for the multiple confounding variables with logistic regression, reporting OR separately for asthma and COPD patients [15]. They concluded that prehospital ICS use was not associated with an increased risk of pneumonia in asthma or COPD patients (OR: 1.07, 95\% CI: 0.61-1.87 for asthma; OR: 1.4, 95\% CI: 0.95-2.09 for COPD). In a retrospective analysis of 62 patients, To et al. were not able to establish an association between ICS and pneumonia in asthma patients after excluding COPD patients [16]. Almiral et al. in a casecontrol study studied ICS use in asthma patients and COPD patients separately [17]. After adjusting for the confounders, they did not notice any association of ICS with pneumonia in asthma patients.

\section{Randomized Controlled Trials}

The strongest evidence comes from the retrospective analysis of the data from double-blinded clinical trials sponsored by AstraZeneca (Table 3).

\begin{tabular}{|c|c|c|c|c|c|c|}
\hline Source & $\begin{array}{l}\text { Age } \\
\text { group }\end{array}$ & $\begin{array}{l}\text { No. of } \\
\text { patients }\end{array}$ & $\begin{array}{l}\text { COPD } \\
\text { excluded }\end{array}$ & $\begin{array}{l}\text { Study } \\
\text { duration }\end{array}$ & Study type & Result \\
\hline $\begin{array}{l}\text { Sheffer et } \\
\text { al. [18] }\end{array}$ & $\begin{array}{l}5-66 \\
\text { years }\end{array}$ & T,221 & Yes & 3 years & Budesonide versus placebo & $\begin{array}{l}\text { No difference }(2.4 \% \text { in the budesonide group } \\
\text { versus } 3.1 \% \text { in the placebo group) }\end{array}$ \\
\hline $\begin{array}{l}\text { Woodcock } \\
\text { et al. [19] }\end{array}$ & $\begin{array}{l}\geq 12 \\
\text { years }\end{array}$ & 646 & Yes & 8 weeks & $\begin{array}{l}\text { Five different groups of fluticasone } \\
\text { furoate dosing versus placebo }\end{array}$ & $\begin{array}{l}\text { Similar incidence to placebo in upper } \\
\text { respiratory infection and respiratory tract } \\
\text { infection; pneumonia not reported }\end{array}$ \\
\hline $\begin{array}{l}\text { Noonan et } \\
\text { al. [20] }\end{array}$ & $\begin{array}{l}\geq 12 \\
\text { years }\end{array}$ & 596 & Yes & weeks & $\begin{array}{l}\text { Four different groups of budesonide } \\
\text { and/or formoterol dosing and } \\
\text { formulation versus placebo }\end{array}$ & Pneumonıa not reported \\
\hline $\begin{array}{l}\text { O'Byrne et } \\
\text { al. [21] }\end{array}$ & Varies & & & & $\begin{array}{l}\text { Meta-analysis of RCT ( } 26 \text { trials and } 60 \\
\text { trials) }\end{array}$ & No increased risk of pneumonıa \\
\hline
\end{tabular}

TABLE 3: RCTs on the risk of pneumonia with ICS and their outcomes

COPD, chronic obstructive pulmonary disease; RCT, randomized controlled trial; ICS, inhaled corticosteroids

Sheffer et al. conducted the START (Steroid Treatment As Regular Therapy) trial with 7,221 patients. They reported that budesonide does not confer any increased risk of pneumonia when compared with placebo in the three-year duration of the study (2.4\% pneumonia in the budesonide group versus $3.1 \%$ in the placebo group) [18]. Woodcock et al. compared five different formulations of fluticasone furoate with placebo [19]. In the clinical trial safety outcomes, they did not report increased lower respiratory tract infections conferred to fluticasone compared with placebo. Noonan et al. conducted an RCT of 12 weeks' duration with budesonide and formoterol formulations, but pneumonia incidence was not reported [20].

Perhaps, the best overview of RCTs on the subject can be O'Byrne et al.'s meta-analysis [21]. The study included 26 trials and a total of 14,993 patients in the primary dataset, with all trials having at least one treatment arm with budesonide and one placebo. The relative risk (RR) for pneumonia as an adverse effect was 0.52 (95\% CI: 0.36-0.76; P = 0.001) and RR for pneumonia as a serious adverse effect was 1.29 (95\% CI: $0.53-3.12 ; \mathrm{P}=0.58$ ). The results were not supportive of an increased risk of pneumonia with ICS use. The secondary dataset of the study included 60 trials with 33,496 patients exposed to budesonide and 2,273 patients exposed to fluticasone and showed similar results. The meta-analysis demonstrated that the use of ICS in asthma patients has no evidence for an increased risk of pneumonia. There was no increased risk with 
higher doses of budesonide or any difference between budesonide and fluticasone in the trials analyzed in the secondary dataset.

\section{Fluticasone versus Budesonide}

In observational studies in which COPD patients were not excluded, fluticasone was demonstrated to have an increased risk of pneumonia compared with budesonide (Table 4).

\begin{tabular}{|c|c|c|c|c|c|c|}
\hline Source & $\begin{array}{l}\text { Age } \\
\text { group }\end{array}$ & $\begin{array}{l}\text { No. of } \\
\text { patients }\end{array}$ & COPD excluded & Study type & Result & $95 \% \mathrm{Cl}$ \\
\hline \multirow{2}{*}{$\begin{array}{l}\text { Ekbom et al. } \\
\text { [13] }\end{array}$} & \multirow{2}{*}{$\begin{array}{l}20-44 \\
\text { years }\end{array}$} & \multirow{2}{*}{7,284} & \multirow{2}{*}{$\begin{array}{l}\text { No; asthma self-reported } \\
\text { diagnosis }\end{array}$} & \multirow{2}{*}{ Hospital/no hospitalization } & IRR: 7.92 for fluticasone & $0.92-6.68$ \\
\hline & & & & & IRR: 1.23 for Budesonide & $1.23-4.2$ \\
\hline \multirow{2}{*}{$\begin{array}{l}\text { McKeever et } \\
\text { al. [14] }\end{array}$} & \multirow{2}{*}{$\begin{array}{l}18-80 \\
\text { years }\end{array}$} & \multirow{2}{*}{43,169} & \multirow{2}{*}{ Yes } & \multirow{2}{*}{$\begin{array}{l}\text { Pneumonia/no pneumonia } \\
\text { (case-control) }\end{array}$} & OR: 1.64 for fluticasone & $1.5-1.79$ \\
\hline & & & & & OR: 1.2 for budesonide & $1.06-1.35$ \\
\hline To et al. [16] & $\begin{array}{l}16-83 \\
\text { years }\end{array}$ & 62 & Yes & Asthma ICS/asthma non-ICS & \multicolumn{2}{|c|}{$\begin{array}{l}\text { No difference between low-, medium-, and } \\
\text { high-dose groups }\end{array}$} \\
\hline
\end{tabular}

TABLE 4: Comparison of risk of pneumonia between fluticasone and budesonide

COPD, chronic obstructive pulmonary disease; CI, confidence interval; IRR, incidence risk ratio; OR, odds ratio; ICS, inhaled corticosteroids

Ekbom et al. also showed an increased IRR of 7.92 for fluticasone (95\% CI: 0.92-6.68) and IRR of 1.23 for budesonide (95\% CI: 1.23-4.2) [13]. McKeever's study excluded COPD patients and associated the use of fluticasone inhaler (OR, 1.64; 95\% CI, 1.50-1.79; P = 0.001) and budesonide inhaler (OR: 1.20; 95\% CI: 1.06$1.35 ; \mathrm{P}=0.003$ ) with a higher risk of pneumonia or lower respiratory tract infection [14]. However, in To et al.'s study where COPD patients were excluded, there was no difference in pneumonia risk among low-, medium-, and high-dose groups [16]. In RCTs, there was no difference in pneumonia risk among fluticasone and budesonide [21].

\section{Conclusions}

We noticed that the observational studies that reported an increased risk of pneumonia with ICS use did not exclude COPD. When COPD patients were excluded, observational studies did not report an increased risk of pneumonia associated with ICS use. All the clinical trials reported no increased risk conferred by ICS use with pneumonia in asthma patients. Fluticasone seems to be associated with a slightly higher risk of pneumonia in observational studies. However, the findings were not replicated in RCTs. We conclude that ICS use is not associated with increased risk of pneumonia in asthma patients and that COPD patients should be excluded in future studies concerning the risk of pneumonia in asthma patients associated with ICS use.

\section{Additional Information}

\section{Disclosures}

Conflicts of interest: In compliance with the ICMJE uniform disclosure form, all authors declare the following: Payment/services info: All authors have declared that no financial support was received from any organization for the submitted work. Financial relationships: All authors have declared that they have no financial relationships at present or within the previous three years with any organizations that might have an interest in the submitted work. Other relationships: All authors have declared that there are no other relationships or activities that could appear to have influenced the submitted work.

\section{References}

1. National Asthma Education and Prevention Program : Expert Panel Report 3 (EPR- 3): Guidelines for the diagnosis and management of asthma-summary report 2007. J Allergy Clin Immunol. 2007, 120:S94. 10.1016/j.jaci.2007.09.043

2. Bateman ED, Bousquet J, Keech ML, Busse WW, Clark TJH, Pedersen SE: The correlation between asthma control and health status: the GOAL study. Eur Respir J. 2007, 29:56-62. 10.1183/09031936.00128505

3. Kochanek KD, Murphy SL, Xu J, Arias E: Deaths: final data for 2017. Natl Vital Stat Rep. 2019, 68:1-76.

4. Dremsizov T, Clermont G, Kellum JA, Kalassian KG, Fine MJ, Angus DC: Severe sepsis in communityacquired pneumonia: when does it happen, and do systemic inflammatory response syndrome criteria help predict course?. Chest. 2006, 129:968-978. 10.1378/chest.129.4.968

5. Ernst P, Gonzalez A V, Brassard P, Suissa S: Inhaled corticosteroid use in chronic obstructive pulmonary 

10.1164/rccm.200611-16300C

6. Drummond MB, Dasenbrook EC, Pitz MW, Murphy DJ, Fan E: Inhaled corticosteroids in patients with stable chronic obstructive pulmonary disease: a systematic review and meta-analysis. JAMA. 2008, 300:2407-2416. 10.1001/jama.2008.717

7. Kew KM, Seniukovich A: Inhaled steroids and risk of pneumonia for chronic obstructive pulmonary disease . Cochrane Database Syst Rev. 2014, 2014:CD010115. 10.1002/14651858.CD010115.pub2

8. Zaidi SR, Blakey JD: Why are people with asthma susceptible to pneumonia? A review of factors related to upper airway bacteria. Respirology. 2019, 24:423-430. 10.1111/resp.13528

9. Talbot TR, Hartert TV, Mitchel E, et al.: Asthma as a risk factor for invasive pneumococcal disease . N Engl J Med. 2005, 352:2082-2090. 10.1056/NEJMoa044113

10. Brode SK, Campitelli MA, Kwong JC, et al.: The risk of mycobacterial infections associated with inhaled corticosteroid use. Eur Respir J. 2017, 50:1700037. 10.1183/13993003.00037-2017

11. Hojo M, Iikura M, Hirano S, Sugiyama H, Kobayashi N, Kudo K: Increased risk of nontuberculous mycobacterial infection in asthmatic patients using long-term inhaled corticosteroid therapy. Respirology. 2012, 17:185-190. 10.1111/j.1440-1843.2011.02076.x

12. Kim MH, Rhee CK, Shim JS, et al.: Inhaled corticosteroids in asthma and the risk of pneumonia . Allergy Asthma Immunol Res. 2019, 11:795-805. 10.4168/aair.2019.11.6.795

13. Ekbom E, Quint J, Schöler L, et al.: Asthma and treatment with inhaled corticosteroids: associations with hospitalisations with pneumonia. BMC Pulm Med. 2019, 19:254. 10.1186/s12890-019-1025-1

14. McKeever T, Harrison TW, Hubbard R, et al.: Inhaled corticosteroids and the risk of pneumonia in people with asthma: a case-control study. Chest. 2013, 144:1788-1794. 10.1378/chest.13-0871

15. Festic E, Bansal V, Gajic O, Lee AS: Prehospital use of inhaled corticosteroids and point prevalence of pneumonia at the time of hospital admission: secondary analysis of a multicenter cohort study. Mayo Clin Proc. 2014, 89:154-162. 10.1016/j.mayocp.2013.10.028

16. 16. To M, To Y, Yamada H, Ogawa C, Otomo M, Suzuki N, Sano Y: Influence of inhaled corticosteroids on community-acquired pneumonia in patients with bronchial asthma. Intern Med. 2004, 43:674-678. 10.2169/internalmedicine.43.674

17. Almirall J, Bolíbar I, Serra-Prat M, et al.: Inhaled drugs as risk factors for community-acquired pneumonia . Eur Respir J. 2010, 36:1080-1087. 10.1183/09031936.00022909

18. Sheffer AL, Silverman M, Woolcock AJ, Díaz P V, Lindberg B, Lindmark B: Long-term safety of once-daily budesonide in patients with early-onset mild persistent asthma: results of the Inhaled Steroid Treatment as Regular Therapy in Early Asthma (START) study. Ann Allergy Asthma Immunol. 2005, 94:48-54. 10.1016/S1081-1206(10)61285-9

19. Woodcock A, Bateman ED, Busse WW, et al.: Efficacy in asthma of once-daily treatment with fluticasone furoate: a randomized, placebo-controlled trial. Respir Res. 2011, 12:132. 10.1186/1465-9921-12-132

20. Noonan M, Rosenwasser LJ, Martin P, O'Brien CD, O'Dowd L: Efficacy and safety of budesonide and formoterol in one pressurised metered-dose inhaler in adults and adolescents with moderate to severe asthma. Drugs. 2006, 66:2235-2254. 10.2165/00003495-200666170-00006

21. O'Byrne PM, Pedersen S, Carlsson LG, et al.: Risks of pneumonia in patients with asthma taking inhaled corticosteroids. Am J Respir Crit Care Med. 2011, 183:589-595. 10.1164/rccm.201005-06940C 